\title{
The Wide Fuel and its Characteristics
}

\author{
Kaushal.K.Vaghasiya \\ B.E.CHEMICAL \\ OM. Engineering College \\ Junagadh, India \\ kaushalvaghasiya13@gmail.com
}

\author{
Jaimin.J.Kacha \\ B.E.CHEMICAL \\ OM. Engineering College \\ Junagadh, India \\ jaiminkacha28198@gmail.com
}

\author{
Nevin.N.Thumar \\ B.E.CHEMICAL \\ OM. Engineering College \\ Junagadh, India \\ nevinthumar1@gmail.com
}

\author{
Prof.V.D.Pandit \\ Assistant Professor \\ OM. Engineering College \\ Junagadh, India \\ panditvishva@ymail.com
}

\author{
Harshit.J.Rupapara \\ B.E.CHEMICAL \\ OM. Engineering College \\ Junagadh, India \\ harshitrupapara7@gmail.com
}

\begin{abstract}
Water in diesel emulsion is an optional fuel, has a potential to reduce the formation of both nitrogen oxides, carbon dioxides and particulate matters in diesel engine. Thus the performance of this emulsified fuel strongly depends on the type of emulsion, stability of emulsion, amount of surfactant and the physio-chemical properties. In this study, water in diesel emulsion fuels of 5\%, 10\%, 20\%, 25\% water by volume was prepared by a mechanical stirrer. Physical and chemical properties of emulsion were examined as this properties could influence the spray characteristic of the emulsion which can affect the ignition delay and flame propagation, the carbon contents for emulsified fuel with $10 \%$ and $20 \%$ were low droplet size of the emulsion was found to be less than $2 \mu \mathrm{m}$. The water content in the emulsified fuel also include the amount of surfactant density and viscosity was found to be higher for all of the water in diesel emulsion the pure diesel.
\end{abstract}

Keywords-Emulsified fuel, surfactant, droplet size, emulsion properties flash and fire point, viscosity, density, calorific value.

$* * * * *$

\section{INTRODUCTION}

In spite of preferable advantages of diesel engines, they are one of the major pollution contributors to present time. Such primary pollutants exhausted from diesel engines are particulate matters (PM), nitrogen oxides (NOx), Sulphur oxides $\left(\mathrm{SO}_{\mathrm{X}}\right)$, unburnt hydrocarbon $(\mathrm{HC})$, carbon monoxide (CO), and carbon dioxide $\left(\mathrm{CO}_{2}\right)$ [1]. Emulsion of diesel and water are often promoted as being able to overcome the difficulty of simultaneously reducing emissions of both $\mathrm{NO}_{\mathrm{X}}$ and PM from the diesel engines [2]. The main mechanism causing the reduction in NOx emissions seems to be the decrease in the temperature of the combustion products as a result of vaporization of the liquid water and consequent dilution of the gas phase species. As for PM emissions, the presence of water during the intensive formation of soot particles seems to reduce the rate of formation of soot particles and enhance their burnout by increased concentration of oxidation species such as $\mathrm{OH}$ [3]. The aim of the present study is to obtain stable water in diesel emulsion (WiDE) which is stabilized with surfactants, in order to reduce operating costs, emissions and fuel consumptions of any internal-combustion engine. Primary step before using WiDE as a fuel is to characterize their properties as it will influence certain operating parameter of the engine such as injection timing and mixing process [4]. Besides that, it was found that physical and chemical kinetics of the combustion is influenced by the presence of water vapor in fuel [5].

\section{METHODOLOGY}

Two-phase water in diesel emulsion (WiDE) as shown in figure 1. It was prepared using mechanical stirrer, with above 1200 RPM. Four blends of WiDE with 5\%, 10\%, 20\%, 25\% water by volume very prepared. The flash point and fire point were measure by pensky martens apparatus. Calorific value of the fuel were obtained using digital bomb calorimeter. Chemical characteristic were analyzed using CHNSanalyzer. Stability of the WiDE was visually observed. Water droplet and distribution was captured by using microscope and measurement of droplet size done using software toupview3.7 .

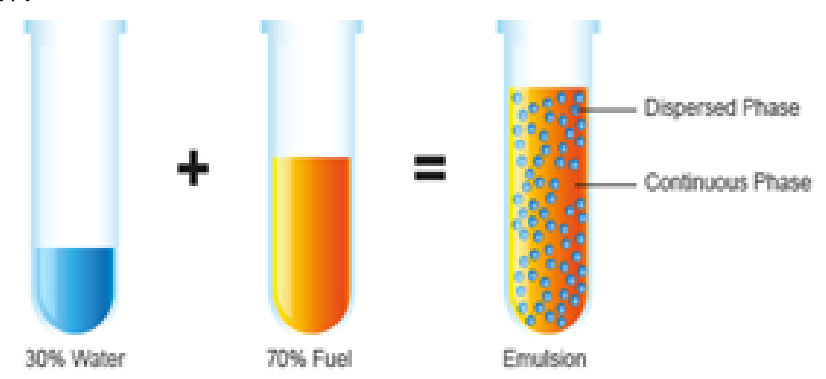

Fig.1 concept of two phase water-in-diesel 


\section{RESULTS AND DISCUSSIONS}

The most important factor in the preparation of emulsion is the selection of suitable surfactants or blend of surfactants which can satisfactory emulsify the chosen ingredients at a specific temperature. Emulsification is greatly influenced by hydrophile-lipophile balance (HLB) of any surfactants [7]. Percentage of water in emulsion, stirring speed and duration, types of surfactants are the parameters that affect the stability of an emulsion. The current study was observed for more than 40 days. Since it was emulsified and found to be stable as shown in figure 2.1 and 2.2. It was observed that the larger the amount of water content in the emulsion, the brighter milky emulsion is produced. The $20 \%$ and $25 \%$ emulsion samples are more brighter milky then $5 \%$ and $10 \%$ sample.

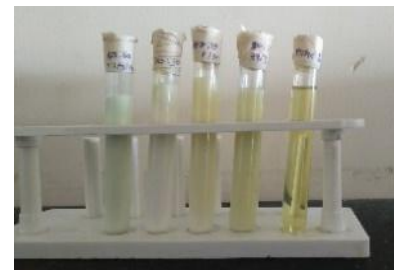

Fig.2.1 Before

Fig. $2.1 \& 2.2$ Stable WiDE samples with $5 \%$ to $25 \%$ water

\section{A. Water content of WiDE}

The water content of WiDE is sum of amount of water and surfactants shown in table 1 for $100 \mathrm{ml}$ emulsion sample.

\begin{tabular}{|c|c|c|c|}
\hline SAMPLE & $\begin{array}{c}\text { DIESEL } \\
\text { (ML) }\end{array}$ & $\begin{array}{c}\text { WATER } \\
\text { (ML) }\end{array}$ & $\begin{array}{c}\text { SURFACTANTS } \\
\text { (ML) }\end{array}$ \\
\hline WiDE-5 & 95 & 3 & 2 \\
\hline WiDE-10 & 90 & 8 & 2 \\
\hline WiDE-20 & 80 & 18 & 2 \\
\hline WiDE-25 & 75 & 23 & 2 \\
\hline
\end{tabular}

Table:-1 Water Content of WiDE

The amount of water content varies where the amount of surfactants used are same for the study. The presence of water in WiDE is a key issue to be addressed. Since it will affect the ignition delay timing $[8,9]$.

\section{B. Flash point and Fire point of WiDE Samples}

The flash point and fire point analysis of WiDE samples are very important parameters for understanding fuel characteristics and for pure diesel fuel. Flash points very between $40^{\circ} \mathrm{C}$ to $96^{\circ} \mathrm{C}$. The fuel must have a high auto ignition temperature. The flash and fire point of $100 \mathrm{ml}$ emulsion samples are shown in below table 1.1.

\begin{tabular}{|c|c|c|c|c|c|}
\hline SAMPLE & \multicolumn{2}{|l|}{ SURFACTANTS } & $\begin{array}{c}\text { MIXING } \\
\text { TIME }\end{array}$ & $\begin{array}{c}\text { FLASH } \\
\text { POINT }\end{array}$ & $\begin{array}{c}\text { FIRE } \\
\text { POINT }\end{array}$ \\
\hline & $\boldsymbol{S}$-1 & $\boldsymbol{S}-2$ & & & \\
\hline Pure Diesel & $0 \mathrm{ml}$ & $0 \mathrm{ml}$ & $0 \mathrm{~min}$ & $41^{\circ} \mathrm{C}$ & $47^{\circ} \mathrm{C}$ \\
\hline WiDE-5 & $0.5 \mathrm{ml}$ & $1.5 \mathrm{ml}$ & $10 \mathrm{~min}$ & $43^{\circ} \mathrm{C}$ & $52^{\circ} \mathrm{C}$ \\
\hline WiDE-10 & $0.5 \mathrm{ml}$ & $1.5 \mathrm{ml}$ & $10 \mathrm{~min}$ & $47^{\circ} \mathrm{C}$ & $56^{\circ} \mathrm{C}$ \\
\hline WiDE-15 & $0.5 \mathrm{ml}$ & $1.5 \mathrm{ml}$ & $10 \mathrm{~min}$ & $49^{\circ} \mathrm{C}$ & $60^{\circ} \mathrm{C}$ \\
\hline WiDE-20 & $0.5 \mathrm{ml}$ & $1.5 \mathrm{ml}$ & $10 \mathrm{~min}$ & $50^{\circ} \mathrm{C}$ & $63^{\circ} \mathrm{C}$ \\
\hline WiDE-25 & $0.5 \mathrm{ml}$ & $1.5 \mathrm{ml}$ & $10 \mathrm{~min}$ & $55^{\circ} \mathrm{C}$ & $66^{\circ} \mathrm{C}$ \\
\hline WiDE-30 & $0.5 \mathrm{ml}$ & $1.5 \mathrm{ml}$ & $10 \mathrm{~min}$ & $59^{\circ} \mathrm{C}$ & $71^{\circ} \mathrm{C}$ \\
\hline WiDE-35 & $0.5 \mathrm{ml}$ & $1.5 \mathrm{ml}$ & $10 \mathrm{~min}$ & $67^{\circ} \mathrm{C}$ & $77^{\circ} \mathrm{C}$ \\
\hline WiDE-40 & $0.5 \mathrm{ml}$ & $1.5 \mathrm{ml}$ & $10 \mathrm{~min}$ & $73^{\circ} \mathrm{C}$ & $83^{\circ} \mathrm{C}$ \\
\hline
\end{tabular}

Table:-1.1 Flash And Fire Point Analysis

The water percentage increase the flash point and fire point. Difference between flash point and fire point is approx $10^{\circ} \mathrm{C}$.

\section{Calorific Value Analysis}

The gross calorific value of WiDE was decreased with increase in water content as shown in table 1.2. The amount of water leads to lower heating value of WiDE and can be attributed to slight reduction in engine power when used as fuel.

\begin{tabular}{|c|c|}
\hline SAMPLE & $\begin{array}{c}\text { CALORIFIC VALUE } \\
\text { (CAL/GM) }\end{array}$ \\
\hline WiDE-5 & 6610 \\
\hline WiDE-10 & 6250 \\
\hline WiDE-15 & 5582 \\
\hline WiDE-20 & 5520 \\
\hline WiDE-25 & 4500 \\
\hline \multicolumn{2}{|c|}{ Table:-1.2 calorific Analysis } \\
\hline
\end{tabular}

\section{Density Analysis}

The density of WiDE sample increases with increase in water content as shown in graph.The density of samples increases around 0.006 to 0.008 when increase in water percentage is $5 \%$.

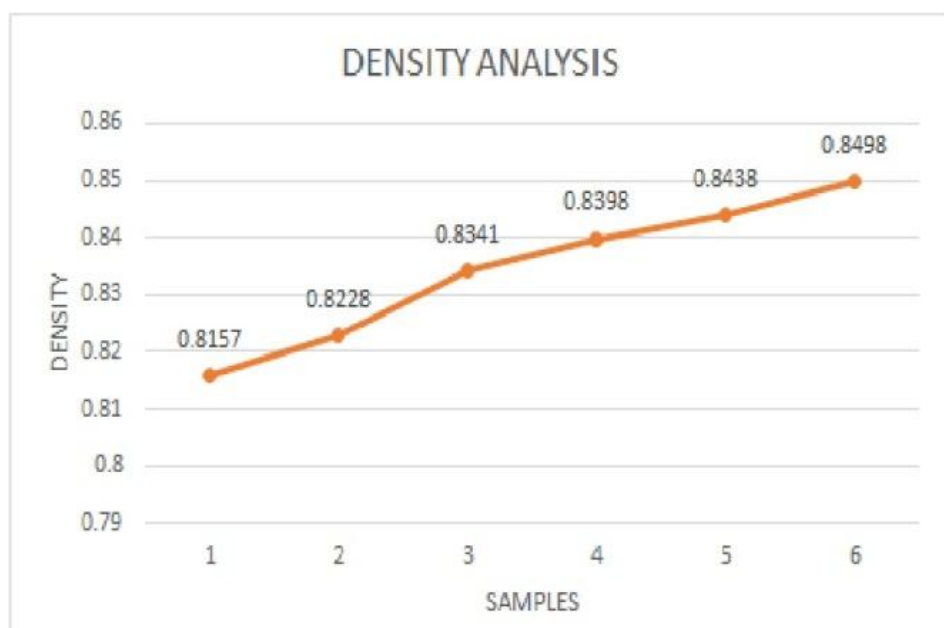

Figure 3-density analysis chart 


\section{E. Stability Check of WiDE Samples}

Stability of the WiDE samples is affected mainly by the fraction of water, stirring speed and concentration of surfactants. The stability of samples varies around 40 to 56 days which is shown in fig $2.1 \& 2.2$.

\section{F. CHNS Analysis}

Carbon content was higher in diesel compare to WiDE with $5 \%$ water. Which can be attributed to the influence of surfactant along with lesser water. Also carbon content in WiDE with $10 \%$ and $20 \%$ water were less compared to diesel. Hydrogen percentage was higher inWiDE of $5 \%$ and $10 \%$ compare to pure diesel. The surfactants used are easily burn with no soot and free of Sulphur and nitrogen [10]. All the CHNS analysis data are shown in table 1.4.

\begin{tabular}{|c|c|c|c|c|}
\hline SAMPLE & $\begin{array}{c}\text { CARBON } \\
\text { (W/W)\% }\end{array}$ & $\begin{array}{c}\text { HYDROGEN } \\
\text { (W/W)\% }\end{array}$ & $\begin{array}{c}\text { NITROGEN } \\
\text { (W/W)\% }\end{array}$ & $\begin{array}{c}\text { SULPHUR } \\
\text { (W/W)\% }\end{array}$ \\
\hline $\begin{array}{c}\text { Pure } \\
\text { Diesel }\end{array}$ & 81.36 & 11.83 & 0.1012 & 0.1255 \\
\hline WiDE-5 & 86.30 & 16.316 & 0.1124 & 0.1023 \\
\hline WiDE-10 & 78.60 & 12.401 & 0.191 & 0.0679 \\
\hline WiDE-15 & 73.80 & 11.067 & 0.207 & 0.0589 \\
\hline WiDE-20 & 68.89 & 9.731 & 0.223 & 0.0479 \\
\hline \multicolumn{5}{|r}{ Table:-1.4 CHNS Analysis }
\end{tabular}

\section{G. Viscosity Analysis}

Engler viscometer used to find viscosity of WiDE and diesel for the temperature range as shown in table 1.5. for analysis water bath temperature taken between $50^{\circ} \mathrm{C}$ to $60^{\circ} \mathrm{C}$ where WiDE and diesel temperature is taken around $40^{\circ} \mathrm{C}$ to $42^{\circ} \mathrm{C}$.

\begin{tabular}{|c|c|c|c|c|}
\hline Stante & TEMPERATLRE & $\begin{array}{l}\text { TIME } \\
\left.(g)^{\prime}\right)\end{array}$ & $\begin{array}{c}\text { KINEMATIC VISCOSITY } \\
\left(\mathrm{cm}^{\prime} / \mathrm{sec}\right)\end{array}$ & $\begin{array}{l}\text { ABSOLUTE VISCOSITY } \\
\text { (kemsec) }\end{array}$ \\
\hline \multirow{2}{*}{$\begin{array}{l}\text { Purt } \\
\text { Diesel }\end{array}$} & $29^{\circ} \mathrm{C}$ & 64 & 0.1382 & $1.1273 \% 10^{5}$ \\
\hline & $41^{\circ} \mathrm{C}$ & 56 & 0.1134 & $0.925 \cdot 10^{5}$ \\
\hline \multirow[b]{2}{*}{ WIDE.S } & $29^{\circ} \mathrm{C}$ & 70 & 0.1563 & $12858^{*} 10^{5}$ \\
\hline & $41^{\circ} \mathrm{C}$ & 60 & 0.1260 & $10367 \cdot 10^{5}$ \\
\hline \multirow[b]{2}{*}{ WIDE-10 } & $29^{\circ} \mathrm{C}$ & 76 & 0.1739 & $1.4504 \% 10^{5}$ \\
\hline & $41^{\circ} \mathrm{C}$ & 64 & 0.1383 & $1.1535 \div 10^{5}$ \\
\hline \multirow[b]{2}{*}{ WDE-15 } & $29^{\circ} \mathrm{C}$ & 78 & 0.1797 & $15091^{4} 10^{5}$ \\
\hline & $41^{\circ} \mathrm{C}$ & 71 & 0.1992 & $15369^{*} 10^{5}$ \\
\hline \multirow[b]{2}{*}{ WDE-20 } & $29^{\circ} \mathrm{C}$ & 103 & 0.2503 & $2.1120 \times 10^{5}$ \\
\hline & $41^{\circ} \mathrm{C}$ & 97 & 0.2336 & $19711^{*} 10^{5}$ \\
\hline
\end{tabular}

\section{CAlCUlation EQUATION}

Kinematic viscosity

$$
\mathbf{V}=(\mathbf{A} * \mathbf{t})-(\mathrm{B} / \mathrm{t})
$$

Where $A=0.0026 \mathrm{~cm}^{2} / \mathrm{sec}^{2}$

$$
\mathrm{B}=1.8 \mathrm{~cm}^{2}
$$

Absolute viscosity

$$
\mathbf{N}=\mathbf{V} * \rho(\mathrm{kg} /(\mathrm{m} . \mathrm{sec}))
$$

The viscosity difference between WiDE-5 and WiDE-10 is small. Viscosity and density variation between WiDE-5 and WiDE-10 are significant and is due to the reduction in actual water content in the mixture which was not maintained.

\section{WATER DISTRIBUTION AND DROPLET DIAMETER}

The distribution of water in WiDE of $10 \%$ and $20 \%$ are shown in figure 4(a) and 4(b). The images were captured by microscope with $400 \mathrm{X}$ magnification. It was concluded that droplet diameter of the micro-emulsion would not vary beyond 0.1 to $20 \mu \mathrm{m}$. the smaller droplets evaporate more quickly and form a better air-fuel mixture. Hence the reduction in soot when the mixture burns [11-13]. Figures show that means droplet diameters are in acceptable range for all the two WiDE sample.

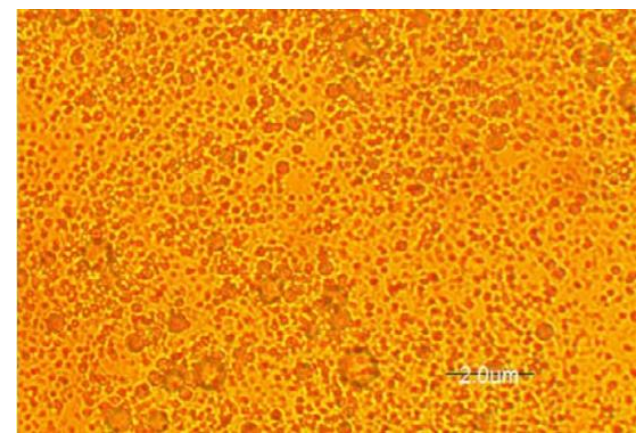

Figure 4(a) WiDE-5

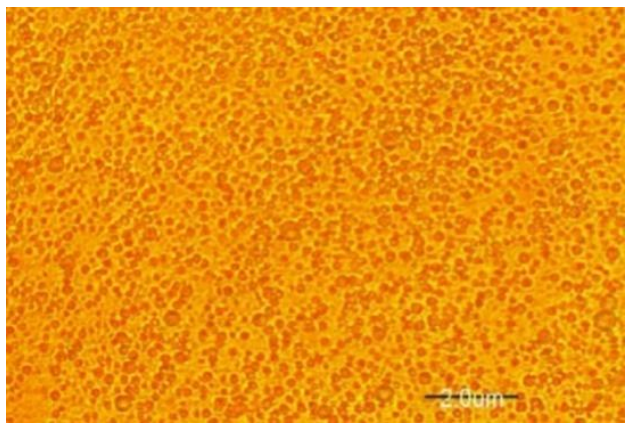

Figure 4(b) WiDE-10

\section{TORQUE ANALYSIS OF WIDE}

The torque data analysis of WiDE is done in Tata diesel engine with 1500 R.P.M capacity. The torque of pure diesel is measured $45-50 \mathrm{~kg}$. Compare to torque of pure diesel the torque of $\mathrm{WiDE}$ is $65-70 \mathrm{~kg}$. The torque of WiDE-10 is measured around $75-80 \mathrm{~kg}$.

\section{CONCLUSION}

Two-phase stable water in diesel emulsion (WiDE) with 5\%, $10 \%, 20 \%$ and $25 \%$ water were successfully prepared using mechanical stirrer and their physical and chemical properties were examined and discussed in detail.Droplet sizes of less than $2 \mu \mathrm{m}$ were achieved. We concluded that Increase in water 
$\%$ increases the flash point and fire point.Difference between flash point and fire is approx $10^{\circ} \mathrm{C}$.

Stability of the diesel emulsion is affected mainly by the fraction of water, stirring speed and conc. of surfactant. We concluded that adding emulsifier increases the stability of emulsion. Also we concluded that calorific value of samples decreases by increase in water percentage

We concluded that density of sample increases around 0.006 to 0.008 when increase in water percentage is $5 \%$.Also we concluded that the engine torque increases by use of WiDE samples. We concluded that $\mathrm{CO}_{2}$ emission decreases by increase in water percentage. Also according to WiDE sample use and type we have to change nozzle spray in diesel engine.

\section{REFERENCES}

[1] C.Y Lin, K.H Wang, Fuel 82, 1367-1375 (2003).

[2] E.A.Fahd, Y.Wenming, P.S. Lee, S.K. Chou, C.R Yap, Apply Energy 102, 1042-1049 (2013).

[3] T. Xuan-Thien, G. Jamil, 5th Asia Pacific Conference on Combustion, (2005).

[4] O. Armas, R. Ballesteros, F.J. Martos, J.R. Agudelo, Fuel 84, 1011-1018 (2005).

[5] A. Alahmer, Energy Conversion and Management 73, 361-369 (2013).

[6] M. Yahiya Khan, Z. A. Abdul Karim, F.Y.Hagos, A. R. A. Aziz, I. M. Tan, TSWJ (2014).

[7] M.J. Rosen, Surfactants and interfacial phenomenon. Wiley; (2004).

[8] I. Jeong, K.H Lee, J. Kim, J Mech Sci and Tech22, 148-156, 2008

[9] A. Subramanian, Energy Conversion and Management 52, 849857 (2011).

[10] Y. Zeng and C.F. Lee, Proc. of the Combustion Institute. 31, 2185-2193 (2007).

[11] K.C. Tsao, X. Yong, SAE, 891883 (1989).

[12] T.Kadota, H.Yamasaki, Prog. Energy Combust. Sci. 28, 385404 (2002).

[13] Y.Morozumi, Y. Saito, Energy Fuels 24, 1854-1859 (2010). 